\title{
CIRCUM-NAVEGAÇÃO E O EXPANSIONISMO ESTADUNIDENSE NO SÉCULO XIX
}

GUILHERME FERREIRA OLIVEIRA*

RESENHA DE: Junqueira, MARY ANNE. VELAS aO MAR. U.S. EXPLORING EXPEDITION (1838-1842). A VIAGEM CIENTÍFICA DE CIRCUM-NAVEGAÇÃO DOS NORTE-AMERICANOS. SÃO PAULO: INTERMEIOS, 20 15. 250 P.

Alguns trabalhos historiográficos contribuem significativamente graças a sua análise cuidadosa e pormenorizada do objeto de estudo, outras têm seu brilhantismo na qualidade e no teor do material utilizado como fonte. Podemos dizer que o livro Velas ao Mar compreende esses dois aspectos com êxito. A autora, Mary A. Junqueira, professora dos programas de História e Relações Internacionais da Universidade de São Paulo (USP), é reconhecida como umas das principais referências no Brasil para o estudo da História dos Estados Unidos e das narrativas e práticas estabelecidas entre esse país e a América Latina.

Nesse livro, M. A. Junqueira traz uma pesquisa de fôlego, fruto de oito anos de investigação, e que Ihe rendeu a tese de livre-docência. Ela aí analisa a primeira viagem de circum-navegação organizada pela marinha norte-americana, entre os anos de 1838 e 1842, a qual tinha uma multiplicidade de intenções, desde investidas científicas, até interesses geopolíticos e estratégicos, e porque não dizer, simbólicos. Para tanto, movimentaram-se 346 homens, desde marinheiros a artistas e naturalistas, liderados pelo controverso capitão Charles Wilkes (1798 - 1878), os quais produziram um acervo monumental, que conta com um relatório de viagem de 23 volumes, sendo que os cinco primeiros foram dedicados propriamente à narrativa da viagem, e os outros versam sobre temas variados como a classificação de animais, plantas e também de seres humanos.

Certamente um dos principais feitos do livro é a sua contribuição a um assunto que, surpreendentemente, esteve por muito tempo ofuscado da memória nacional norte-americana - que, com frequência, ancora-se no passado para fortalecer imaginários como o do excepecionalismo. Como destaca a autora, a expedição esteve por tempos no esquecimento, inclusive entre os acadêmicos, e as principais publicações 
sobre o tema são voltadas para um público mais amplo ${ }^{1}$. Outro ponto de destaque é que o livro aparece como importante exercício de escrita pós-colonial e transnacional, e assim a expedição emerge como "percursora na constituição de um conjunto de saberes elaborados pelo governo norte-americano sobre a América Latina e outras regiões do globo" (Junqueira, 2015, p. 22).

Infere-se assim que para os Estados Unidos, que naquele tempo mobilizava forças para o processo de consolidação do Estado nacional - em 1838, contava-se 62 anos da Independência -, a expedição teve um claro objetivo estratégico de demarcar seu espaço no mundo enquanto país produtor e detentor de conhecimento. Até então, as viagens de circum-navegação eram realizadas pelos ingleses, franceses e russos, e com a U.S. Exploring Expedition, os Estados Unidos afirmam a ampliação de seus interesses no campo da geopolítica. Internamente, a expedição contribuiu ainda para a expansão territorial que o Estado já fazia desde o início daquele século. Por exemplo, o conhecimento adquirido foi fundamental na guerra contra o México, quando os Estados Unidos conquistam a região da atual Califórnia, em 1846, e quando em 1848, anexaram o território do atual Oregon, que até então pertencia ao Reino Unido. Estendia-se, assim, suas fronteiras até o Pacífico.

A historiadora divide seu livro em duas partes compostas de três e quatro capítulos, respectivamente. Na primeira parte, a autora contextualiza a U. S. Exploring Expedition no cenário das expedições de circum-navegação que vinham sendo realizadas pelos europeus desde a segunda metade do século XVIII. A constituição dessas viagens se deu com base em um diálogo profícuo entre os países envolvidos, gerando um conjunto de saberes que extrapolavam os limites nacionais. Acumulavam-se assim, para além de conhecimentos náuticos, da geografia e das culturas visitadas, também informações que permitiram a elaboração das coordenadas geográficas, como a longitude que não aconteceu, diga-se de passagem, sem conflitos e tensões, sobretudo ao atribuir-se Greenwich como o meridiano zero.

Nesse contexto, a U.S. Exploring Expedition cumpriu um papel crucial, a partir de um cuidadoso mapeamento do Atlântico, que levou à feitura de cartas náuticas, à verificação de topografias e à aferição de distâncias. Vemos aqui a clara intenção dos Estados Unidos em produzir um conhecimento que pudesse ser caracterizado como

\footnotetext{
${ }^{1}$ Os trabalhos são: Philbrick, 2005; Viola, 1985.
} 
um conjunto de saberes "nacionais", elaborando um discurso próprio que foi organizado por marinheiros e cientistas norte-americanos, e que passou a integrar, assim, as "redes de conhecimento transnacionais". Como destaca o antropólogo Johannes Fabian, "não há conhecimento sobre o Outro que não seja também um ato temporal, histórico e político" (Fabian, 2013, p. 40). O caso da U. S. Exploring Expedition parece não deixar dúvidas sobre isso.

Na segunda parte, Mary A. Junqueira explora a formação de uma cultura imperial que pode ser percebida na narrativa de viagem da expedição. Antes, contudo, a autora faz um interessante balanço sobre os limites e as possibilidades do relato de viagem como fonte histórica, uma vez que esse é um "gênero" híbrido e essencialmente heterogêneo, que desde sempre havia despertado interesse de um público vasto. Todas essas questões envolvidas na produção do relato influenciam, inclusive, em seu resultado final, que pode estar carregado de ornamentações literárias, questões institucionais, memórias e recursos estéticos, e cabe ao historiador o cuidado na apreciação do documento.

No penúltimo capítulo, aparecem importantes informações para os interessados nas interpretações da América do Sul elaboradas ao longo do século XIX. Certamente imbuído do repertório da época, Charles Wilkes preocupa-se com a caracterização e a hierarquização dos grupos distribuídos pelo globo, e a categoria de raça ocupa aqui um lugar central. Isso porque Wilkes utiliza-se largamente do termo para interpretar os costumes e as práticas dos lugares onde visitou, associando comportamentos e culturas com o conceito de raça ou de classe, que aparecem como sinônimos. Essa classificação serve ainda para a exaltação da chamada raça anglo-saxônica, descrita como superior e mais evoluída no quadro dos grupos humanos.

Por fim, resta considerar que a obra é de grande importância não apenas para os estudiosos dos Estados Unidos e das relações travadas pelo país e por seus agentes ao longo do século XIX. Notadamente nesse aspecto, a contribuição já é de grande valia. Porém, o convite à leitura estende-se também a todos os que procuram entender a formação das potências mundiais e, sobretudo, os esforços daquele país, que na segunda metade do século XIX ainda não havia se consolidado totalmente como um estado nacional - vide a Guerra Civil, que dividiu nortistas e sulistas entre os anos de 1861 e 1865 -, mas que no século XX se estruturaria como uma das grandes nações 
imperialistas, expandido seus interesses por todo o mundo conhecido.

\section{REFERÊNCIAS}

FABIAN, Johannes. O tempo e o outro. Como a antropologia estabelece seu objeto. Petrópolis, RJ: Vozes, 2013.

PHILBRICK, Nathaniel. Mar de glória. Viagem Americana de descobrimento. São Paulo: Companhia das Letras, 2005.

VIOLA, Herman J; MARGOLIS, Carolyn (orgs.). Magnificent voyagers. The U. S. Exploring Expedition, 1838 - 1842. Washington: Smithsonian Institution Press, 1985. 